\title{
Penerapan Metode Promethee Sebagai Sistem Pendukung Keputusan Pemeringkatan Siswa
}

\author{
Ronal Watrianthos $^{1}$, Kusmanto ${ }^{2}$, Elida F. S. Simanjorang ${ }^{1}$, Muhammad Syaifullah ${ }^{3}$, Ibnu Rasyid Munthe ${ }^{1}$ \\ ${ }^{1}$ Universitas Labuhan Batu, Rantauprapat, Indonesia \\ ${ }^{2}$ Universitas Al-Washliyah Labuhan Batu, Rantauprapat, Indonesia \\ ${ }^{3}$ STMIK-AMIK Riau, Indonesia \\ Email: 1'ronal.watrianthos@gmail.com, ${ }^{2 k u s n a b a r a 03 @ g m a i l . c o m, ~}{ }^{3}$ buelida.dosenku@gmail.com, \\ ${ }^{4}$ muhammadsyaifullah@stmik-amikriau.ac.id, ${ }^{5}$ ibnurasyidmunthe@gmail.com
}

\begin{abstract}
Abstrak
Pemeringkatan siswa memerlukan sejumlah pertimbangan dan kriteria-kriteria. Penentuan kriteria harus disiapkan semaksimal mungkin karena terkait dengan pemilihan siswa berprestasi. Namun penentuan peringkat ini dianggap kurang optimal dan tidak efisien karena diproses secara manual oleh pihak sekolah. Diperlukan Sistem Pendukung Keputusan yang tepat agar bisa menghasilkan keputusan pemeringkatan yang cepat dan akurat. Penelitian ini menggunakan metode Preference Ranking Organization Method for Enrichment Evaluation (PROMETHEE) sebagai Sistem Pendukung Keputusan. Metode ini akan menggunakan multikriteria sebagai masukan utama dalam pengambilan keputusan. PROMETHEE akan digunakan untuk menganalisa kriteria berdasarkan alternatif yang dibandingkan sehingga dapat menyusun peringkat berdasarkan nilai dan kemampuan siswa. Berdasarkan data sampel penelitian, nilai tertinggi didapatkan sebesar 0,739 untuk alternatif A16. Ini menunjukkan bahwa alternatif A16 merupakan alternatif terbaik dibandingkan alternatif-alternatif lainnya berdasarkan pertimbangan semua kriteria. Pengembangan PROMETHEE dengan Sistem Pendukung Keputusan berbasis aplikasi jauh lebih baik karena menghasilkan perhitungan yang cepat dan akurat.
\end{abstract}

Kata Kunci: Sistem Pendukung Keputusan, Pemeringkatan, Siswa, PROMETHEE

\begin{abstract}
Students rank requires several considerations and criteria. Determination of the criteria must be prepared as much as possible because it is related to the selection of outstanding students. However, this ranking is considered less than optimal and requires a long time because it is processed manually by the school. The right Decision Support System is needed to produce quick and accurate ranking decisions. This study uses the Preference Ranking Organization Method for Enrichment Evaluation (PROMETHEE) as a Decision Support System. This method will use multi-criteria as the main input in decision making. PROMETHEE will be used to analyze criteria based on alternatives compared to rank according to students' grades and abilities. Based on the research sample data, the highest value was 0.739 for alternative A16. This shows that alternative A16 is the best alternative compared to other alternatives based on consideration of all criteria. The development of PROMETHEE with application-based Decision Support Systems is much better because it produces fast and accurate calculations.
\end{abstract}

Keywords: Decision Support System, Ranking, Students, PROMETHEE

\section{PENDAHULUAN}

Dalam pemeringkatan siswa, diperlukan sejumlah pertimbangan dan kriteria-kriteria seperti nilai akademik, nilai ekstrakurikuler, nilai praktikum, nilai absensi, kepribadian, dan kriteria lainnya sesuai dengan kebijakan institusi[1]. Penentuan kriteria harus disiapkan semaksimal mungkin karena terkait dengan pemilihan siswa berprestasi. Pemilihan siswa berprestasi ini menjadi penting karena siswa merupakan subjek utama pendidikan sehingga sehingga prestasi menjadi parameter keberhasilan pendidikan[2].

Penentuan peringkat siswa biasanya diproses secara manual oleh pihak sekolah. Hal ini dianggap kurang optimal dan tidak efisien sehingga memiliki kelemahan yang bisa menimbulkan persoalan. Terjadinya kemungkinan human error juga tinggi dalam proses pengolahan datanya[3]. Diperlukan sistem pendukung keputusan berbasis teknologi informasi untuk menghasilkan keputusan pemeringkatan yang cepat dan akurat.

Dukungan teknologi informasi dalam membantu membuat keputusan atau dikenal dengan nama Sistem Pendukung Keputusan (SPK) saat ini telah banyak digunakan. SPK dianggap bisa memberikan solusi dari masalah yang kompleks, memiliki respon yang cepat terhadap perubahan kondisi, mampu menerapkan berbagai strategi dengan konfigurasi yang berbeda, serta memiliki keputusan yang lebih tepat[4]. Selain itu, SPK juga lebih hemat biaya serta mampu mengontrol manajemen sehingga efektifitas dan kinerja manajerial lebih meningkat[5].

Konsep Sistem Pendukung Keputusan pertama kali diperkenalkan oleh Michael S. Cott Morton pada tahun 1970 dengan tujuan membantu suatu pengambilan keputusan berbasis komputer dengan menggunakan data dan model tertentu[6]. Sedangkan Decision Support System atau Sistem Pendukung Keputusan konsepnya lebih tergantung kepada basis data sebagai sumber datanya dan menekankan fungsi pendukung dalam pembuat keputusan[7]. Sistem Pendukung Keputusan juga bisa digunakan sebagai sebuah aplikasi dalam membantu membuat keputusan[8] dengan menggunakan data dan model tertentu untuk menyelesaikan masalah yang tidak terstruktur menjadi terstruktur[9]. Dalam pengambilan keputusan, kesulitan-kesulitan seperti pemrosesan nilai atau pemilihan kriteria akan mempengaruhi[10].

Banyak metode yang digunakan dalam Sistem Pendukung Keputusan. Salah satunya adalah metode Preference Ranking Organization Method for Enrichment Evaluation (PROMETHEE) yang akan digunakan dalam penelitian ini. Metode ini dapat menggunakan berbagai kriteria sebagai input utama dalam pengambilan 
keputusan[8]. PROMETHEE akan digunakan untuk menganalisa kriteria berdasarkan alternatif yang dibandingkan sehingga dapat menyusun peringkat berdasarkan nilai dan kemampuan siswa.

\section{TEORITIS}

\subsection{Sistem Pendukung Keputusan}

Suatu organisasi dalam melakukan pengambilan keputusan merupakan hasil komunikasi yang melibatkan seluruh organisasi[11]. Pengambilan keputusan dalam suatu organisasi menjadi penting karena ketepatan pengambilan keputusan dapat mempengaruhi keberlangsungan suatu organisasi[6]. Implementasi proses pengambilan keputusan dalam organisasi tercermin dari sistem operasional, sistem manajemen, dan sistem informasinya[12]. Proses pengambilan keputusan pada dasarnya adalah bentuk pemilihan menggunakan berbagai tindakan alternatif untuk menghasilkan keputusan yang terbaik[8].

Kelengkapan dan keakuratan informasi sangat berpengaruh besar dalam proses pengambilan keputusan, sehingga ketersediaan informasi perlu didukung oleh sebuah sistem informasi. Sistem informasi yang mampu menyediakan informasi, pemodelan, dan manipulasi data sehingga bisa membantu dalam pengambilan keputusan akan melahirkan Sistem Pendukung Keputusan[7][12].

Sistem Pendukung Keputusan dapat memberi keuntungan bagi pemakainya[13], antara lain:

1. Meningkatkan kecepatan dalam pengambilan keputusan ketika memproses data/informasi.

2. Meningkatkan efisiensi dalam pengambilan keputusan, terutama dalam masalah yang sangat kompleks dan tidak terstruktur.

3. Meningkatkan kecepatan pengambilan keputusan dengan hasil yang dapat dihandalkan.

4. Membantu pengambil keputusan sebagai keputusan alternatif dalam mengambil keputusan.

5. Membantu pengambil keputusan dalam memberikan justifikasi terhadap keputusan yang telah ditetapkan.

Selain memberikan keuntungan, Sistem Pendukung Keputusan masih memiliki sejumah keterbatasan[8], seperti:

1. Kemampuan dan bakat manusia tidak selalu bisa dimodelkan, sehingga sistem tidak dapat mencerminkan masalah sebenarnya.

2. Kemampuan Sistem Pendukung Keputusan terbatas kepada pengetahuan yang dimiliki oleh pengembangnya.

3. Kemampuan Sistem Pendukung Keputusan bergantung kepada perangkat lunak yang digunakan.

4. Sistem Pendukung Keputusan tidak memiliki emosi dan intuisi seperti manusia, sehingga keputusan yang dihasilkan mungkin tidak bisa diadaptasikan dengan kondisi sebenarnya.

\subsection{Metode PROMETHEE}

PROMETHEE (Preference Ranking Organization Method for Enrichment Evaluation) merupakan metode pengambilan keputusan multikriteria[14][15], sesuai dengan metode Multi Criteria Decision Making (MCDM) yang dikembangkan oleh Brans dan Vincke. Metode ini dapat digunakan untuk menemukan keputusan terbaik berdasarkan penilaian kriteria tertentu dan bekerja dengan menentukan urutan berdasarkan prioritas dalam analisa multi-kriteria, baik pada data kuantitatif ataupun kualitatif dengan isu kejelasan, kestabilan, dan kesederhanaan sebagai hal utama[12].

Metode PROMETHEE termasuk dalam metode dengan pendekatan outranking (peringkatan) dengan prinsip penetapan prioritas aternatif berdasarkan persamaan (1)

$\operatorname{Max}\left\{f_{1}(x), f_{2}(x), f_{3}(x), \ldots, f_{i}(x) I x \in A\right\}$

Persamaan (1) dimana A merupakan kumpulan dari alternatif pilihan yang mungkin terjadi, sedangkan $\mathrm{f}_{1}$, $\mathrm{f}_{2}, \ldots \mathrm{f}_{\mathrm{k}}$ adalah kriteria yang telah dievaluasi sebelumnya. Apabila semua kriteria memiliki kepentingan yang tidak sama, pembobotannya akan ditandai dengan $\mathrm{w}_{1}, \mathrm{w}_{2}, \ldots . \mathrm{w}_{\mathrm{k}}$. Nilai hubungan outranking dihasilkan dengan dasar pertimbangan pada setiap dominasi kriteria. Preferensi dari pembuat keputusan ditentukan dari indeks preferensi dan nilai outranking yang didapatkan. Data dasar analisis PROMETHEE dapat dilihat pada Tabel 1 berikut[16].

Tabel 1. Data Dasar Analisis PROMETHEE

\begin{tabular}{|c|c|c|c|c|c|c|}
\hline & $\mathrm{f}_{1}()$. & $\mathrm{f}_{2}()$. & & $\mathrm{f}_{\mathrm{j}}()$. & & $\mathrm{f}_{\mathrm{k}}()$. \\
\hline & $\mathrm{w}_{1}$ & $\mathrm{w}_{2}$ & $\ldots$ & $\mathrm{w}_{\mathrm{j}}$ & $\ldots$ & $\mathrm{w}_{\mathrm{k}}$ \\
\hline$a_{1}$ & $\begin{array}{c}\mathrm{f}_{1} \\
\left(\mathrm{a}_{1}\right)\end{array}$ & $\begin{array}{c}\mathrm{f}_{2} \\
\left(\mathrm{a}_{1}\right)\end{array}$ & $\ldots$ & $\begin{array}{c}\mathrm{f}_{\mathrm{j}} \\
\left(\mathrm{a}_{1}\right)\end{array}$ & $\ldots$ & $\begin{array}{c}\mathrm{f}_{\mathrm{k}} \\
\left(\mathrm{a}_{1}\right)\end{array}$ \\
\hline 12 & $\begin{array}{c}\mathrm{f}_{1} \\
\left(\mathrm{a}_{2}\right)\end{array}$ & $\begin{array}{c}\mathrm{f}_{2} \\
\left(\mathrm{a}_{2}\right)\end{array}$ & $\cdots$ & $\begin{array}{c}\mathrm{f}_{\mathrm{j}} \\
\left(\mathrm{a}_{2}\right)\end{array}$ & $\ldots$ & $\begin{array}{c}\mathrm{f}_{\mathrm{k}} \\
\left(\mathrm{a}_{2}\right)\end{array}$ \\
\hline . & $\cdots$ & 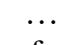 & $\ldots$ & $\cdots$ & $\ldots$ & $\ldots$ \\
\hline$a_{i}$ & $\begin{array}{r}f_{1} \\
\left(a_{i}\right)\end{array}$ & $\begin{array}{c}\mathrm{f}_{2} \\
\left(\mathrm{a}_{\mathrm{i}}\right)\end{array}$ & $\ldots$ & $\begin{array}{c}\mathrm{f}_{\mathrm{j}} \\
\left(\mathrm{a}_{\mathrm{i}}\right)\end{array}$ & $\ldots$ & $\begin{array}{c}f_{k} \\
\left(a_{i}\right)\end{array}$ \\
\hline & $\begin{array}{c}\mathrm{f}_{1} \\
\left(\mathrm{a}_{\mathrm{n}}\right)\end{array}$ & $\begin{array}{c}\mathrm{f}_{2} \\
\left(\mathrm{a}_{\mathrm{n}}\right)\end{array}$ & $\ldots$ & $\begin{array}{c}\mathrm{f}_{\mathrm{j}} \\
\left(\mathrm{a}_{\mathrm{n}}\right)\end{array}$ & $\ldots$ & $\begin{array}{c}\mathrm{f}_{\mathrm{k}} \\
\left(\mathrm{a}_{\mathrm{n}}\right)\end{array}$ \\
\hline
\end{tabular}


Pada Tabel 1 dinyatakan $a_{i}$ merupakan alternatif dari nilai $i$ sedangkan $f_{k}\left(a_{i}\right)$ merupakan kriteria yang ditetapkan untuk alternatif $i$. Struktur preferensi dalam metode PROMETHEE dibangun dalam kriteria berdasarkan persamaan (2).

$\forall a, b \in A\} f(a)>(b) a P b$

Struktur kriteria yang ditunjukkan persamaan (2) mempunyai arti bahwa setiap alternatif $a$ yang merupakan elemen himpunan $A$, apabila mempunyai nilai alternatif untuk kriteria yang ditetapkan lebih dari nilai alternatif $b$, maka alternatif $a$ akan dipilih daripada alternatif $b$.

$f(a), f(b)\} f(a)=f(b)$ a $I b$

Sedangkan dalam persamaan (3), apabila nilai alternatif $a$ mempunyai nilai yang sama dengan alternatif $b$, maka dapat disimpulkan alternatif $a$ tidak mempunyai perbedaan dengan alternatif $b$, sehingga perlu diperhatikan nilai dari alternatif lainnya. Dalam persamaan (2) dan (3) nilai $f$ merupakan nilai real dari suatu kriteria dengan tujuan untuk mengoptimasi setiap prosedur pada setiap alternatif yang diseleksi.

\subsection{Pemeringkatan PROMETHEE}

Metode PROMETHEE dalam penerapannya akan melakukan perhitungan dengan cara membandingkan setiap alternatif pertama dengan alternatif kedua, ketiga, dan seterusnya. Adapun langkah-langkah dalam perhitungan pemeringkatan PROMETHEE sebagai Sistem Pendukung Keputusan adalah[8]:

1. Menentukan nilai alternatif dari data dengan cara memilih kriteria-kriteria (dominasi kriteria) yang digunakan dalam Sistem Pendukung Keputusan.

2. Menentukan fungsi prefensi dan nilai prefensi.

3. Menghitung indeks preferensi.

4. Pemeringkatan PROMETHEE, dengan menghitung arah preferensi yang dipertimbangkan berdasarkan nilai indeks preferensi, leaving flow, entering flow, dan net flow.

Indeks preferensi dilakukan dengan menetapkan fungsi preferensi $\mathrm{P}_{1}$ dan $\mu i$ untuk semua kriteria $\mathrm{f}_{1}(\mathrm{I}=1, \ldots \mathrm{n})$ sebagai optimasi multikriteria. Bobot $\mu i$ memiliki ukuran yang relatif dari nilai kepentingan kriteria $\mathrm{f}_{1}$. Kriteria yang memiliki nilai kepentingan yang sama dalam pengambilan keputusan maka nilai bobotnya juga sama. Perhitungan indeks preferensi dilakukan pada persamaan (4) berikut[1].

$\varphi(a, b)=\sum_{i=1}^{n} \pi P_{i}(a, b): \forall a, b \in A$

Dimana $\varphi(a, b)$ merupakan intensitas preferensi bagi pembuat keputusan yang dinyatakan bahwa alternatif $a$ lebih baik dari alternatif $b$ melalui pertimbangan masing-masing kriteria. Sedangkan nilai $n$ merupakan jumlah dari kriteria dengan ketentuan $\varphi(a, b)=0$ menunjukkan preferensi alternatif $a$ lemah daripada alternatif $b$ berdasarkan semua kriteria. Sedangkan nilai $\varphi(a, b)=1$ menunjukkan alternatif $a$ memiliki nilai preferensi yang kuat daripada alternatif $b$ berdasarkan semua kriteria.

Perhitungan arah preferensi juga dipertimbangkan berdasarkan nilai indeks leaving flow pada persamaan (5), yaitu nilai positif yang didapatkan dari arah pemeringkatan (positive outranking flow). Nilainya semakin naik apabila dominasi suatu alternatif semakin besar dibandingkan alternatif lainnya. Pertimbangan lainnya juga didapatkan dari nilai entering flow dan net flow seperti pada persamaan (6) dan (7). Entering flow merupakan kebalikan dari leaving flow, karena apabila dominasi suatu alternatif semakin kecil, nilainya juga semakin turun menjadi negative outranking flow. Sedangkan net flow akan dihitung dari nilai selisih antara leaving flow dan entering flow.

$$
\begin{aligned}
& \emptyset^{+}(a)=\frac{1}{n-1} \sum_{x \in A} \wp(a, x) \\
& \emptyset^{-}(a)=\frac{1}{n-1} \sum_{x \in A} \wp(x, a) \\
& \varnothing(a)=\emptyset^{+}(a)-\emptyset^{-}(a)
\end{aligned}
$$

\section{ANALISA DAN PEMBAHASAN}

Proses penilaian dalam menentukan pemeringkatan siswa biasanya dilakukan secara manual. Penilaian dilakukan dengan menggunakan persentase untuk setiap siswa tanpa memperhatikan kriteria yang dimiliki. Nilai setiap siswa yang didapatkan hanya dibandingkan dengan nilai siswa yang lain. Sistem secara manual ini tidak memiliki nilai standar dan parameter tertentu sehingga bobot dari setiap kriteria ditentukan berdasarkan kebijakan pengelola. Dalam kondisi ini, urutan prioritas kriteria dinyatakan berdasarkan nilai parameter dan bobot yang diberikan sehingga sistem hanya memberikan informasi hasil penilaian berdasarkan urutan peringkat. Tabel 2 merupakan contoh pemeringkatan siswa yang telah diberikan nilai alternatif dan nilai kriteria yang akan dihitung dan diurutkan berdasarkan metode PROMETHEE.

Tabel 2. Contoh Tabel Penilaian

\begin{tabular}{cccccccccc}
\hline No & Kriteria & C1 & C2 & C3 & C4 & C5 & C6 & C7 & Total \\
\hline 1 & A1 & 80 & 90 & 77 & 83 & 28 & 42 & 50 & 450 \\
2 & A2 & 80 & 75 & 75 & 85 & 32 & 53 & 60 & 460 \\
3 & A3 & 70 & 80 & 90 & 60 & 40 & 70 & 60 & 470 \\
4 & A4 & 70 & 89 & 78 & 69 & 30 & 54 & 90 & 480
\end{tabular}




\begin{tabular}{cccccccccc}
5 & A5 & 89 & 70 & 78 & 69 & 30 & 44 & 40 & 404 \\
6 & A6 & 66 & 70 & 71 & 89 & 29 & 66 & 40 & 431 \\
7 & A7 & 80 & 66 & 89 & 67 & 33 & 90 & 53 & 478 \\
8 & A8 & 90 & 81 & 77 & 65 & 32 & 76 & 88 & 509 \\
9 & A9 & 87 & 86 & 90 & 66 & 34 & 54 & 78 & 495 \\
10 & A10 & 78 & 68 & 80 & 76 & 33 & 89 & 55 & 479 \\
11 & A11 & 89 & 60 & 60 & 70 & 30 & 78 & 45 & 432 \\
12 & A12 & 75 & 75 & 83 & 70 & 31 & 65 & 76 & 475 \\
13 & A13 & 65 & 65 & 60 & 60 & 30 & 83 & 81 & 444 \\
14 & A14 & 70 & 79 & 64 & 67 & 32 & 91 & 59 & 462 \\
15 & A15 & 70 & 89 & 90 & 66 & 35 & 97 & 69 & 516 \\
16 & A16 & 90 & 90 & 76 & 76 & 35 & 50 & 66 & 483 \\
17 & A17 & 87 & 78 & 60 & 70 & 31 & 90 & 54 & 470 \\
18 & A18 & 65 & 66 & 60 & 71 & 33 & 78 & 85 & 458 \\
19 & A19 & 66 & 76 & 60 & 72 & 32 & 96 & 56 & 458 \\
20 & A20 & 78 & 89 & 67 & 73 & 30 & 88 & 89 & 514 \\
\hline
\end{tabular}

Setelah ditentukan nilai alternatif dan nilai preferensi, kemudian akan dihitung arah preferensi yang dipertimbangkan berdasarkan nilai indeks preferensi seperti pada persamaan (4) sehingga hasil perhitungan data sampel berdasarkan metode PROMETHEE didapatkan seperti pada Tabel 3.

Tabel 3. Tabel Hasil Penilaian Menggunakan PROMETHEE

\begin{tabular}{ccc}
\hline No & Alternatif & Nilai \\
\hline 1 & A1 & 0,735 \\
2 & A2 & 0,685 \\
3 & A3 & 0,66 \\
4 & A4 & 0,679 \\
5 & A5 & 0,679 \\
6 & A6 & 0,62 \\
7 & A7 & 0,65 \\
8 & A8 & 0,70 \\
9 & A9 & 0,723 \\
10 & A10 & 0,67 \\
11 & A11 & 0,618 \\
12 & A12 & 0,658 \\
13 & A13 & 0,53 \\
14 & A14 & 0,644 \\
15 & A15 & 0,7 \\
16 & A16 & 0,739 \\
17 & A17 & 0,655 \\
18 & A18 & 0,59 \\
19 & A19 & 0,619 \\
20 & A20 & 0,675 \\
\hline
\end{tabular}

Tabel 3 merupakan hasil perhitungan menggunakan metode PROMETHEE berdasarkan data pada Tabel 2 dengan nilai tertinggi didapatkan sebesar 0,739 untuk alternatif A16. Ini menunjukkan bahwa alternatif A16 merupakan alternatif terbaik dibandingkan alternatif-alternatif lainnya berdasarkan hasil perhitungan. Hasil ini berbeda dengan perhitungan secara manual berdasarkan data pada Tabel 2 dengan nilai tertinggi 516 untuk alternatif A15.

Setelah hasil didapatkan, penerapan metode PROMETHEE sebagai Sistem Pendukung Keputusan dapat dilihat pada Gambar 1 berikut. 


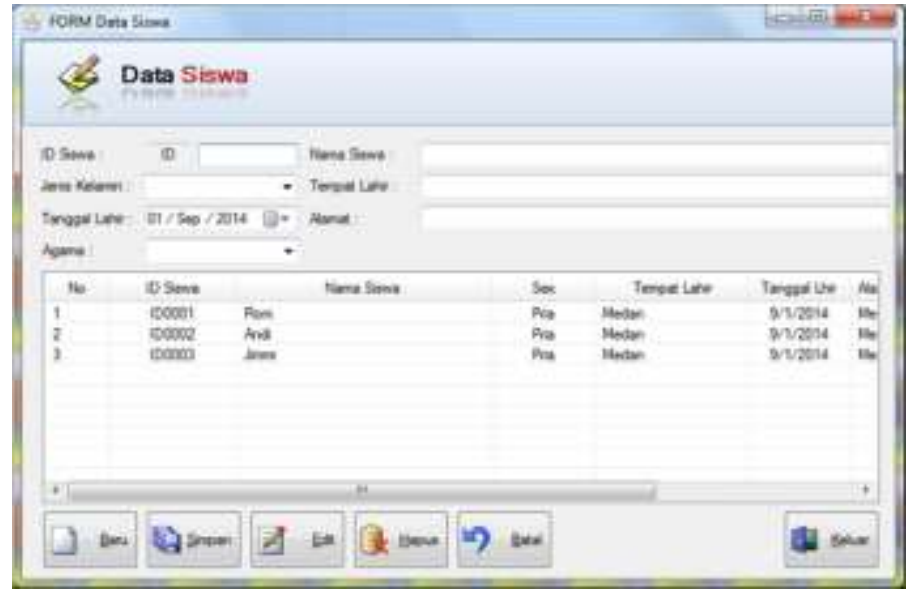

Gambar 1. Input Data Siswa (Nilai Alternatif)

Gambar 1 merupakan rancangan antarmuka untuk memasukkan data siswa yang akan diproses menggunakan metode PROMETHEE. Data siswa ini merupakan data identitas umum seperti ID Siswa, Nama, Tempat Lahir, dan sebagainya. Penentuan data alternatif akan ditentukan berdasarkan data siswa ini dengan menggunakan simbol Alternatif 1 (A1) sampai dengan $A_{n}$. Setelah data alternatif diinput, data nilai kemudian dimasukkan sesuai dengan kriteria dari setiap alternatif. Proses pemetaan data nilai ini bisa dilihat pada Gambar 2.

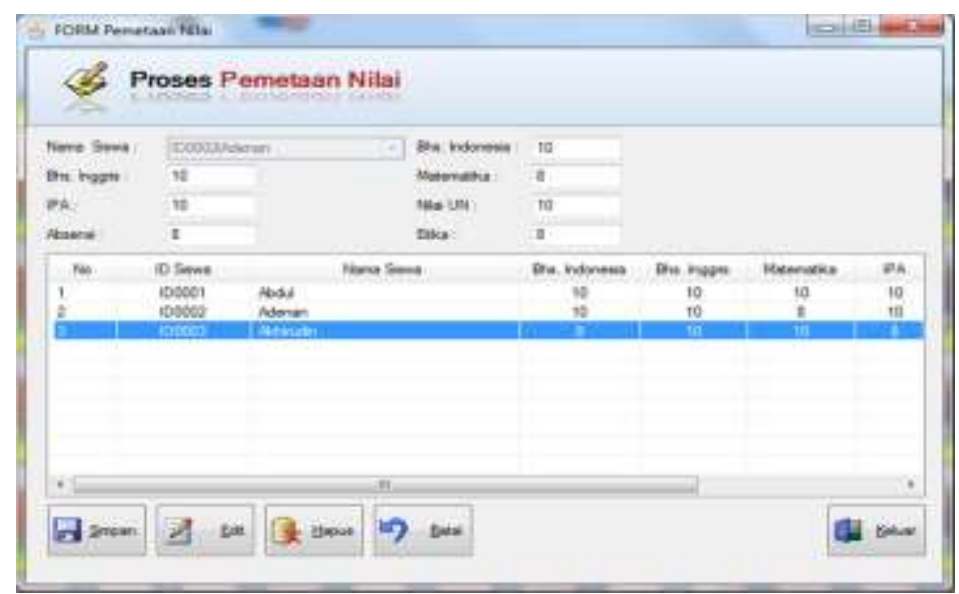

Gambar 2. Proses Pemetaan Nilai (Kriteria)

Setelah pemetaan nilai dilakukan, proses selanjutnya menghitung nilai preferensi dengan menerapkan metode PROMETHEE sesuai sampel data pada Tabel 1. Proses preferensi nilai ini akan ditentukan apabila $\varphi(a, b)=0$ maka alternatif $a$ dianggap lebih lemah dari alternatif $b$ berdasarkan kritera yang ditentukan. Sedangkan apabila $\varphi(a, b)=1$ maka alternatif $a$ dianggap lebih kuat daripada $b$ dari kriteria yang ditentukan. Hasil proses perhitungan preferensi ini dalam bentuk antarmuka ditunjukkan pada Gambar 3 dibawah ini.

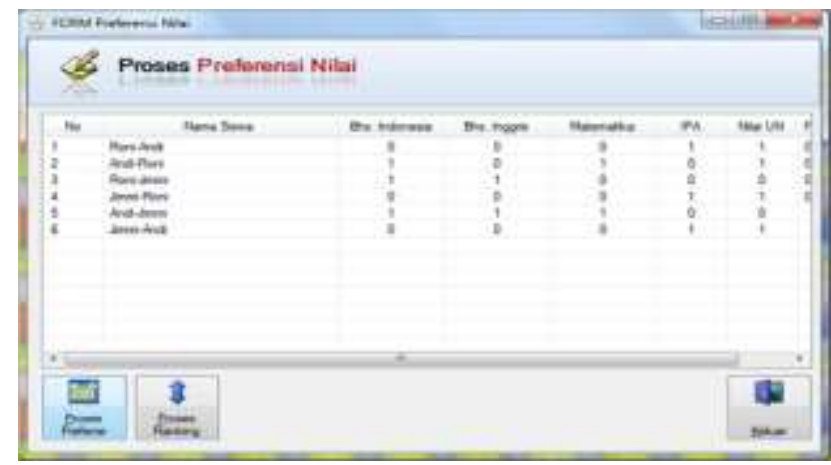

Gambar 3. Nilai Preferensi

Hasil proses preferensi yang ditunjukkan antarmuka pada Gambar 3, terlihat nilai preferensi masing-masing alternatif berdasarkan data sampel pada Tabel 2. Misalnya pada data alternatif 1 perbandingan antara alternatif Roni dengan alternatif Andi menghasilkan nilai 0 untuk kriteria Bahasa Indonesia. Ini menunjukkan bahwa siswa Roni memiliki kemampuan dalam mata pelajaran Bahasa Indonesia lebih lemah dibandingkan siswa Andi. 
Sedangkan untuk mata pelajaran IPA, Roni memiliki kemampuan lebih baik dari Andi karena memiliki nilai preferensi 1.

\section{KESIMPULAN}

Hasil penelitian ini menunjukkan bahwa metode PROMETHEE bisa digunakan sebagai alat menentukan peringkat siswa. Hasil pemeringkatan bergantung kepada nilai kriteria, nilai bobot, serta nilai preferensi. Penerapan metode ini dapat menyelesaikan permasalahan pemilihan siswa berprestasi karena dipilih berdasarkan pemeringkatan multikriteria sehingga membantu pengelola dalam membuat keputusan. Berdasarkan data sampel diatas, hasil perhitungan PROMETHEE untuk peringkat tertinggi dimiliki oleh alternatif A16 dengan nilai 0,739. Perancangan aplikasi Sistem Pendukung Keputusan dengan metode PROMETHEE ini sangat baik karena menghasilkan data yang akurat. Namun metode ini bukanlah satu-satunya sebagai pendukung keputusan dan bisa dikombinasikan dengan metode-metode lain.

\section{REFERENCES}

[1] F. H. Bajandoh and R. Hidayati, "Sistem Pendukung Keputusan untuk Menentukan Siswa Lulusan Terbaik dengan Menggunakan Promethee (Studi Kasus SMA Negeri 3 Pontianak)," Coding J. Komput. dan Apl. Untan, vol. 06, no. 03, pp. 227-236, 2018.

[2] H. B. Uno, Pengantar Teori Belajar dan Pembelajaran. Yogyakarta: Ar-Ruzz Media, 2008.

[3] J. Fitriana, E. F. Ripanti, and T. Tursina, "Sistem Pendukung Keputusan Pemilihan Mahasiswa Berprestasi dengan Metode Profile Matching," J. Sist. dan Teknol. Inf., vol. 6, no. 4, p. 153, 2018.

[4] H. Cucu Handayani, "Implementasi Metode Promethee untuk Menentukan Penerima Kartu Indonesia Pintar ( KIP ) pada Sekolah Menengah Kejuruan,” in Seminar Nasional Multidisiplin 2018, 2018, no. September, pp. 172-180.

[5] H. Pratiwi, Buku Ajar Sistem Pendukung Keputusan. Yogyakarta: Deepublish, 2016.

[6] A. S. Nugroho and H. Himawan, "Sistem Pendukung Keputusan Pemilihan Siswa Terbaik Untuk Kelas Unggulan Di Smp Negeri 6 Semarang Menggunakan Metode Promethee (Preference Ranking Organization Method for Enrichment of Evaluations)," Universitas Dian Nuswantoro Semarang, 2015.

[7] R. Sidabutar, M. Mesran, and N. Sitompul, "Sistem Pendukung Keputusan Seleksi Calon Taruna Pramugara Pada Aerospace Training Centre Menerapkan Metode Promethee Ii," in KOMIK (Konferensi Nasional Teknologi Informasi dan Komputer), 2018, vol. 2, no. 1, pp. $130-137$.

[8] A. P. Nasution, D. A. Harahap, and R. Watrianthos, “Application Decision Support System using PROMETHEE Method,” J. Adv. Res. Dyn. Control Syst., vol. 11, no. 1, pp. 506-511, 2019.

[9] T. L. Saaty, "Decision making - the Analytic Hierarchy and Network Processes (AHP/ANP)," J. Syst. Sci. Syst. Eng., vol. 13, no. 1, pp. $1-35,2004$.

[10] T. Suryanto, R. Rahim, and A. S. Ahmar, "Employee Recruitment Fraud Prevention with the Implementation of Decision Support System,” J. Phys. Conf. Ser., vol. 1028, no. 1, 2018.

[11] A. Indahingwati, M. Barid Nizarudin Wajdi, D. Ermayanti Susilo, N. Kurniasih, and R. Rahim, "Comparison Analysis of TOPSIS and Fuzzy Logic Methods On Fertilizer Selection,” Int. J. Eng. Technol., vol. 7, no. 2.3, p. 109, 2018.

[12] B. Damanik and S. S. Swono Sibagariang, "Penerapan Preference Ranking Organization Method For Enrichment Evaluation (Promethee) Dalam Evaluasi Kinerja Dosen (Studi Kasus: Univ. Sari Mutiara Indonesia)," in KOMIK (Konferensi Nasional Teknologi Informasi dan Komputer), 2018, vol. 2, no. 1.

[13] D. Siregar et al., "Multi-Attribute Decision Making with VIKOR Method for Any Purpose Decision," J. Phys. Conf. Ser., vol. 1019, no. $1,2018$.

[14] M. Mesran, S. D. Nasution, S. Syahputra, A. Karim, and E. Purba, "Implementation of the Extended Promethee II in Upgrade Level of Mechanic,” Int. J. Sci. Res. Sci. Technol., vol. 4, no. 2, pp. 125-130, 2018.

[15] M. A. Majid Behzadian, R.B. Kazemzadeh, A. Albadvi, "PROMETHEE: A comprehensive literature review on methodologies and applicationsOriginal,” Eur. J. Oper. Res., vol. 200, no. 1, pp. 198-215, 2010.

[16] B. Rohmadtulloh and Daryanto, "Sistem Pendukung Keputusan Untuk Menentukan Tingkat Prestasi Pegawai Desainer Dalam Bidang Jasa Percetakan Menggunakan Metode Promethee Pada Cv. Soerabaja 45,” Universitas Muhammadiyah Jember, 2017. 